\title{
Mansikan mustalaikun säilyminen marjaviljelmän kasvillisuudessa
}

\author{
Päivi Parikka ja Anne Lemmetty \\ MTT kasvintuotannon tutkimus, 31600 Jokioinen
}

Mansikan mustalaikku (Colletotrichum acutatum) on tehokas marjojen pilaaja, joka voi tuhota nopeasti marjasadon. C. acutatum oli vielä viime vuonna karanteenituhooja, jonka löy-tyminen suomalaiselta mansikkamaalta johti kasvuston hävittämiseen. Euroopan Unionin kasvinsuojelusäädöksiä on kuitenkin muutettu niin, että C. acutatum on ei ole enää karanteeni-tauti, vaan taimiaineistotuhooja, jota ei saa olla myytävissä taimissa.

C. acutatum esiintyy monilla kasvilajeilla taudinaiheuttajana. Se säilyy piilevänä kas-veissa pitkään ja voi siksi levitä helposti oireettomissa kasveissa. Mansikalta se voi siirtyä pellon rikkakasveihin ja muihin viljelykasveihin. Aikaisemmin Suomessa tehdyissä tutkimuk-sissa on todettu taudinaiheuttajan säilyvän saastuneessa mansikan kasvinjätteessä maassa ai-nakin talven yli, mahdollisesti pidempäänkin. Tämä asettaa vaatimuksia tiloilla noudatettaval-le viljelykierrolle.

Marjaviljelmillä esiintyvien rikkakasvien alttiutta C. acutatum-sienelle on selvitetty MTT kasvinsuojelun tutkimuksessa. Siemenestä lisätyt ja kasvihuoneessa tartutetut kasvit jäivät useimmiten oireettomiksi, mutta silti niistä voitiin osoittaa C. acutatum, myös tartutuksen jälkeen kasvaneista osista. Rikkakasvien lisäksi eräitä kesantokasveja oli mukana kokeissa. Niissä hunajakukka osoittautui araksi mustalaikkusienelle ja sille kehittyi versoihin laikkuja. Taudinaiheuttajan säilymistä talven ja kesän yli maassa ja maan pinnalla tutkittiin maahan upotetuissa ja maalla täytetyissä ruukuissa, joihin kasviainesta sijoitettiin pusseissa maan pinnalle ja 7-9 cm syvyyteen.

Taudinaiheuttajan säilymistä tartutuskykyisenä tutkittiin käyttämällä pyydyskasveina nuoria mansikan taimia. C. acutatum-tartunnan selvittämiseksi näistä pyydyskasveista tehtiin sieniviljelmät sekä PCR määritykset Colletotrichum-spesifisiä alukkeita käyttäen.

Lutukka, piharatamo, voikukka, maitohorsma sekä kesantokasveista kumina ja hunaja-kukka näyttävät säilyttävän tautia ainakin kesän yli kasvinjätteessä maan pinnalla. Talven yli säilyminen vaikuttaa olevan vähäisempää, vain voikukan, valkoapilan, pihatähtimön ja kuminan todettiin säilyttävän tautia. Kaksi- tai monivuotisilla rikoilla, kuten saunakukka ja rönsy-leinikki, tauti voi säilyä talven yli kasveissa. Saunakukka, valkoapila, piharatamo, minttu ja rönsyleinikki pystyivät säilyttämään taudin talven yli ja tartuttamaan sen pyydyskasveihin.

Rikkakasvit ovat potentiaalisia tartuntalähteitä, jos mustalaikkutartunta tulee kasvustoon ja mansikkaa viljellään jatkuvasti samalla lohkolla. Myös valkoapila voi säilyttää tautia kasveissa. Terveet taimet, rikkakasvien tehokas torjunta ja viljelykierto ovat avainasemassa mansikan mustalaikun torjunnassa. Kesantokasvien käyttöä on syytä tarkastella kriittisesti, sillä ne voivat olla uuden tartunnan lähteitä. Muista viljelykasveista kumina vaikuttaa olevan sopimaton mansikkatilan viljelykasviksi. 


\section{Johdanto}

Mansikan mustalaikku havaittiin Suomessa ensimmäisen kerran vuonna 2000 (Parikka \& Kokkola, 2001). Silloin Colletotrichum acutatum-sieni eristettiin Hollannista ostetuista Elsanta-lajikkeen kasveista, joiden marjoissa oli runsaasti tautioireita C. acutatum oli vuoteen 2008 asti luokiteltu Euroopan Yhteisöjen kasvinsuojeludirektiivin mukaan karanteenituhoojaksi. Suomessa taudinaiheuttajan esiintyminen mansikkaviljelmällä johti kasvien hävittämiseen ja kolmen vuoden karanteeniin lohkolla. Lajilla oli jo 1990-luvun lopulla todettu runsaasti isäntäkasveja (Anon., 1997) mutta se oli luokiteltu karanteenituhoojaksi vain mansikalla. Vuonna 2009 C. acutatum on luokiteltu taimiaineistotuhoojaksi, jota ei saa esiintyä myytävässä mansikan lisäysaineistossa. Marjaviljelmillä taudin esiintyminen ei enää aiheuta toimenpiteitä.

Mustalaikun aiheuttaja elää ja lisääntyy kasvien pinnalla (Freeman \& al, 2001, Leandro \& al, 2001) ja pystyy siksi leviämään piilevänä tartuntana. Colletotrichum-lajien diagnostiikka on kehittynyt nopeasti viime vuosina ja vähäinenkin tartunta pystytään havaitsemaan kasveista PCR-menetelmällä käyttämällä eri alukkeita (Martinez-Culebras \& al, 2003, Parikka \& Lemmetty, 2004). Kehittynyt diagnostiikka on myös paljastanut, että useissa aikaisemmin C. gloeosporioides- lajin aiheuttamina pidetyissä taudeissa patogeeni onkin C. acutatum. Norjassa lajia on todettu esiintyvän kirsikalla ja omenalla, pensasmustikalla sekä myös eräillä rikkakasveilla (Stensvand \& al, 2006). Tarkemmat määritysmenetelmät paljastavat jatkuvasti uusia tartuntoja eri kasvilajeilla. Rikkakasvien mahdollisuutta säilyttää ja siirtää tautia mansikkamaalla on tutkittu aikaisemmin Englannissa, missä Berrie ja Burgess (2003) totesivat tartunnan voivan siirtyä rikkakasveilta mansikkaan. Patogeenin säilymistä kasvinjätteissä on tutkittu aikaisemmin Suomessa mansikalla (Parikka \& al. 2006). Tartuntaa ja säilymistä on tutkittu myös keinollisesti tartutetuissa rikkasveissa ja niiden jätteissä (Parikka ja Lemmetty, 2009).

\section{Aineisto ja menetelmät}

\section{Tartutuskokeet rikkakasveilla}

Colletotrichum acutatum-sienen tartuntaa ja säilymistä tutkittiin siemenestä lisätyillä yksivuotisilla ja monivuotisilla rikkakasveilla, eräillä kesantokasveina käytetyillä kasvilajeilla sekä muutamilla monivuotisilla lajeilla. Monivuotisista rikkakasveista osa kasvatettiin kerätyistä taimista ja juurakoista. Yksi- ja kaksivuotisia rikkakasveja oli tartutuskokeissa 10, lajeja olivat jauhosavikka (Chenopodium album), linnunkaali (Lapsana communis), peltovillakko (Senecio vulgaris), pihatähtimö (Stellaria media), peltohatikka (Spergula arvensis), pelto-orvokki (Viola arvensis), lutukka (Capsella bursa-pastoris) ukontatar (Persicaria lapathifolia), saunakukka ( Tripleurospermum maritimum) ja pihasaunio (Matricaria discoidea). Monivuotisia lajeja oli 11, pelto-ohdake (Cirsium arvense), valvatti (Sonchus arvensis), piharatamo (Plantago major), vuohenputki (Aegopodium podagraria), leskenlehti (Tussilago farfara), minttu (Mentha sp) pähkämö (Stachys sp), voikukka ( Taraxacum vulgare), hevonhierakka (Rumex longifolius), suolaheinä (R. acetosa), maitohorsma (Epilobium angustifolium)) ja kesantokasveja 6 lajia: lupiini (Lupinus sp.), hunajakukka (Phacelia tanacetifolia), kumina (Carum carvi), valkoapila (Trifolium repens), sareptansinappi (Brassica juncea) ja auringonkukka (Helianthus annuus).

Kasvit tartutettiin kasvihuoneessa C. acutatum-sienen itiösuspensiolla (2x10 ${ }^{6}$ itiötä/ml). Tartutuksen jälkeen kasvatustiloissa ylläpidettiin 100\% kosteutta 24 h, jonka jälkeen kosteus oli viikon ajan öisin $100 \%$, päivällä ilmankosteus oli normaali. Kasvatuslämpötila oli $25^{\circ} \mathrm{C}$ ja valojakso 16 tuntia. Yksi- ja kaksivuotisista kasveista tarkastettiin oireet ja Colletotrichum-tartunta 5 viikon kasvatusjakson jälkeen. Sen jälkeen kasvit saivat kuivua ja kuiva jäte käytettiin säilyvyystestiin. Monivuotiset kasvit siirrettiin tartutuksen ja kasvatuksen jälkeen ulos talvehtimaan.

\section{Säilyvyystestit ja pyydystyskokeet}

Säilyvyystestiä varten kasvimassa pilkottiin ja pakattiin nylonverkkopusseihin. Pussit asetettiin maan pinnalle ja 7-9 cm syvyyteen maalla täytettyihin ruukkuihin. Ruukut upotettiin maahan. Ensimmäinen Säilyvyyskoe perustettiin keväällä 2007 ja ensimmäiset pussit poistettiin syksyllä. Seuraava koe aloitettiin syksyllä 2007 ja pusseja poistettiin talven jälkeen ja viimeiset seuranneen kesän 2008 jälkeen. Monivuotiset, talvehtineet rikkakasvit siirrettiin kasvamaan kasvihuoneeseen keväällä 2008. Jonkin ajan kuluttua uusi kasvu tuhottiin pitämällä kasveja 1-2 tuntia $-20^{\circ} \mathrm{C}$ lämpötilassa. 
Colletotrichum-sienen tartutuskykyä selvitettiin pyydyskasveilla, joiden tyvelle asetettiin maassa säilytettyä kasvinjätettä. Myös monivuotisten rikkojen pakastamalla tuhottua kasvimassaa käytettiin pyydyskasvien tartuttamiseen. Pyydyskasveina käytettiin nuoria mansikan taimia, lajike 'Jonsok'. Kasveja kasvatettiin tartutuksen jälkeen kasvihuoneessa kuten rikkakasveja Colletotrichum- tartutuksen jälkeen. Pyydystysjakso oli 5 viikkoa, jonka jälkeen kasveista otettiin näytteet juurenniskasta ja lehtiruotien tyviltä maljaukseen (perunadekstroosialusta, PDA) ja PCR-määrityksiin. DNA-eristyksissä käytettiin mansikalle sovellettua menetelmää (Parikka \& Lemmetty, 2004) ja PCR-määrityksissä C. acutatum-spesifisiä alukkeita (Martinez-Culebras \& al, 2003). Myös monivuotisten, talvehtineiden rikkakasvien tartuntaa määritettiin uudesta kasvusta.

\section{Tulokset ja tulosten tarkastelu}

Colletotrichum acutatum ei yleensä aiheuttanut oireita rikkakasveissa, poikkeuksena hunajakukka ja piharatamo, joilla esiintyi laikkuja lehdissä ja versoissa. Maassa säilytetty kuollut kasvinjäte aiheutti pyydyskasveille vain harvoin näkyviä oireita. Lutukka säilytti taudinaiheuttajan hyvin kesäkauden yli ja sen jätteellä tartutettuihin kasveihin kehittyi tummia laikkuja lehtiruoteihin. Maljauksessa sieni kasvoi myös niukasti pyydyskasveista. Vain lutukan ja maitohorsman jätteellä tartutetuista kasveista saatiin PDA-alustalle Colletotrichum-rihmastoa.

PCR määrityksissä havaittiin, että maitohorsma, hunajakukka, kumina, saunakukka, piharatamo, voikukka ja lutukka olivat säilyttäneet $C$. acutatum-sienen kesän yli kuolleessa kasvinjätteessä ja siirtäneet taudin mansikkaan (Parikka ja Lemmetty 2009). Talven yli jatkettu säilytys vähensi selvästi elävää taudinaiheuttajaa. Maan pinnalla ja maalla peitetty kasvinjäte voi kuitenkin edelleen säilyttää tautia, mikä todettiin voikukalla, valkoapilalla, pihatähtimöllä ja kuminalla. Niiden jätteellä tartutetuista pyydyskasveista saatiin positiiviset PCR tulokset (Taulukko 1.).

Monivuotisten, talvehtineiden rikkakasvien uudessa kasvussa ei todettu Colletotrichum-tartuntaa PCR-määrityksessä. Kuitenkin pakastamalla tuhottu ja kuivattu jäte pystyi tartuttamaan pyydyskasveja. Voikukka, valkoapila, piharatamo, minttu ja rönsyleinikki pystyivät siirtämään C. acutatumtartunnan pyydyskasveina käytettyihin mansikan taimiin. Oireita ei kasveissa kuitenkaan havaittu.

Taulukko 1. Colletotrichum acutatum-tartunta keinollisesti saastutetuissa kasveissa ja taudinaiheutta-jan säilyminen kuolleessa kasviaineksessa sekä elävissä monivuotisissa kasveissa. Tartunnan määrä $0=$ ei havaittua tartuntaa, 3= runsaasti tartuntaa. Säilyminen kuolleessa kasviaineksessa, PCR-tulos:0= negatiivinen, $1=$ positiivinen. $\mathrm{x}=$ ei havaintoa.

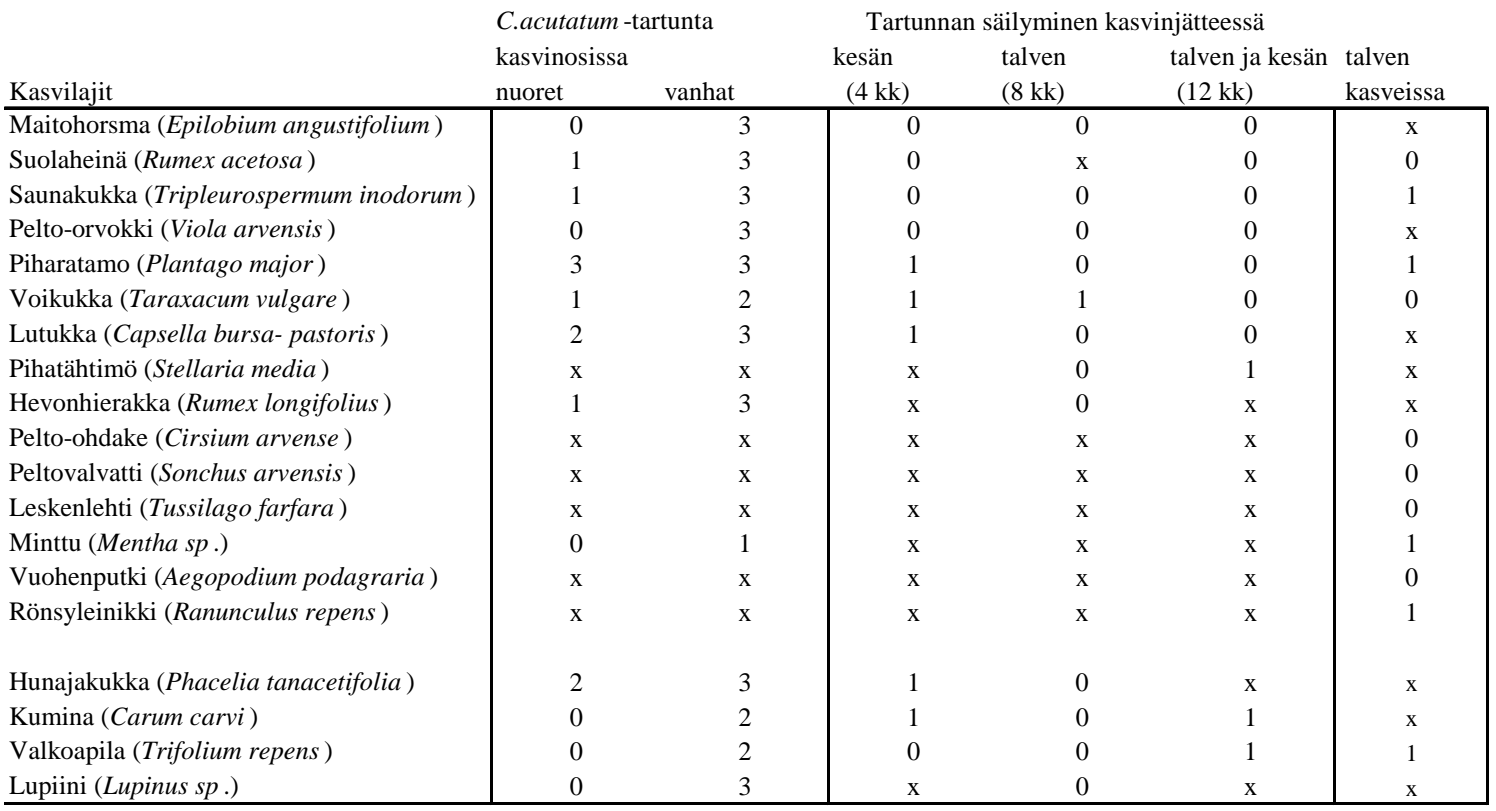


Hevonhierakan on todettu pystyvän saamaan Colletotrichum-tartunnan ja siirtävän sen mansikkaan (Berrie \& Burgess, 2003), mutta tässä kokeessa laji ei säilyttänyt tartuntaa yli kesän. Norjassa nokkoselta on todettu Colletotrichum- tartuntaa mustalaikun saastuttaman mansikkamaan läheisyydessä (Stensvand \& al, 2006), mutta laji ei ollut meillä kokeessa. Lämpötila ja kosteus vaikuttavat voimakkaasti C. acutatum-sienen säilymiseen maassa ja kasvinjätteessä (Eastburn \& Gubler, 1992). Lämpö ja kosteus ylläpitävät mikrobitoimintaa ja nopeuttavat hajoamista. Siksi C. acutatum säilyy kylmän talven yli helpommin kuin sulassa ja lämpimässä maassa. Hitaasti hajoavassa kasvinjätteessä, kuten mansikan juurakoissa se saattaa säilyä jopa lähes kaksi vuotta (Lilja et al, 2006), mutta helposti hajoavassa kasviaineksessa säilymisaika jää lyhyemmäksi. Maan sisään muokattuna jäte hajoaa nopeammin ja säilyttää siksi tauteja huonommin kuin pinnalle jätetty.

\section{Johtopäätökset}

Colletotrichum acutatum on nopea mansikan marjojen pilaaja. Mansikkaviljelmälle päässyt patogeeni leviää ja tuottaa nopeasti runsaasti itiöitä, jotka voivat säilyä elinkykyisinä ja edelleen lisääntyä myös rikkakasvien pinnalla. Kuolleessa kasviaineksessa taudinaiheuttaja voi säilyä, kunnes jäte hajoaa. Tartunta on mahdollista sekä elävistä kasveista että jätteestä, joten rikkakasvien huolellinen torjunta viljelyksiltä on tarpeen. Mustalaikkua ei meillä vielä ole havaittu luontaisina esiintyminä. On kuitenkin todennäköistä, että se tulee meillekin taimikaupan mukana ja leviää marjantuotantoon.

\section{Kirjallisuus}

Anon. 1997. Colletotrichum acutatum. Quarantine Pests for Europe. Second Edition. Data sheets on quarantine pests for the European Union and for the European and Mediterranean Plant Protection Organization. p.692-697. (eds. I.M. Smith, D.G. McNamara, P.R. Scott, M. Holderness and B. Burger). University Press, Cambridge. 1425p.

Berrie, A.M. \& Burgess, C.M. 2003. A review of research on epidemiology and control of blackspot of strawberry (Colletotrichum acutatum) with special reference to weeds as alternative hosts. Proceedings of the IOBC-WPRS Working Group `Integrated Plant Protection In Orchards subgroup 'Soft Fruits', Dundee, Scotland 18-21 September 2001. (eds. S.C. Gordon and J.V. Cross) Bulletin-OILB-STROP 26:163-168.

Eastburn, D.M. \& Gubler, W.D. 1992. Effects of soil Moisture and temperature on the survival of Colletotrichum acutatum. Plant Disease 76:841-842.

Freeman, S., Horowitz, S. \& Sharon, A. 2001. Pathogenic and nonpathogenic lifestyles in Colletotrichum acutatum from strawberry and other plants. Phytopathology 91:986-992.

Leandro, L., Gleason, M.L, Nutter, F.W. Jr., Wegulo, S. \& Dixon, P. 2001. Germination and sporulation of Colletotrichum acutatum on symptomless strawberry leaves. Phytopathology 91:659-664.

Lilja, A., Parikka, P., Pääskynkivi, E., Hantula, J., Vainio, E., Vartiamäki, H., Lemmetty, A. \& Vestberg, M. 2006. Phytophthora cactorum and Colletotrichum acutatum: survival and detection. Agriculturae Conspectus Scientificus 71(4):121-128.

Martinez-Culebras, P.V., Querol, A., Suarez-Fernandez, M.B., Garcia-Lopez, M.D. \& Barrio, E. 2003. Phylogenetic relationships among Colletotrichum pathogens of strawberry and design of PCR primers for their identification. Journal of Phytopathology 151:135-143.

Parikka, P. \& Kokkola, M. 2001. First Report of Colletotrichum acutatum on Strawberry in Finland. Plant Disease 85:923.

Parikka, P. \& Lemmetty, A. 2004. Tracing latent infection of Colletotrichum acutatum on strawberry by PCR. European Journal of Plant Pathology 110:393-398.

Parikka, P. \& Lemmetty, A. 2009. Colletotrichum acutatum: Survival in Plant Debris and Infection of Some Weeds and Cultivated Plants Acta Horticulturae 842:307-310.

Parikka, P., Pääskynkivi, E. \& Lemmetty, A. 2006. Survival of Colletotrichum acutatum in dead plant material and soil in Finland. Acta Hort. 708:131-134.

Stensvand, A., Talgø, V., Strømeng, G.M., Aamot, H.U., Børve, Stensvand, A., Talgø, V., Strømeng, G.M., Aamot, H.U., Børve, J., Sletten, A. \& Klemsdal, S. 2006. Colletotrichum acutatum in Norwegian strawberry production and potential sources of inoculum in and around strawberry fields. IOBC wprs Bulletin 29(9):87-91. 